\title{
Zayed University Students' Teaching and Learning Beliefs and Preferences: An analysis based on the surface versus deep learning approach
}

\author{
Alan Russell \\ Zayed University, Dubai \\ Discuss this paper online at http://groups.yahoo.com/LTHE/
}

\begin{abstract}
Analyses of teaching and learning in higher education are increasingly being based on a distinction between surface and deep learning. This distinction is helpful for investigating approaches used by teachers as well as student preferences for teaching and learning. Surface learning places an emphasis on memorizing facts and information as well as the relatively passive reproduction of content. In contrast, deep learning involves an intention to understand, the critical assessment of content and relating new information to past knowledge in meaningful ways. There has been an assumption that in the U.A.E. there is an orientation to surface learning in schools and higher education. To examine this assumption, an adaptation of questionnaires used with Western students (the Approaches to Study Skills Inventory for Students) was used with a small sample of ZU students. There are limitations in the use of this procedure and difficulties in interpreting the results. However, the results suggest that ZU students show strong beliefs and preference for deep learning approaches in addition to surface learning approaches. This finding is consistent with evidence obtained from student responses to assessment tasks, where there was evidence of deep learning. It was concluded that learning outcomes for ZU students could be enhanced by employing deep learning approaches to teaching and learning.
\end{abstract}

\section{Background}

Discussions about the quality and nature of teaching and learning in higher education have been prominent in the literature in recent decades (Biggs, 1988; Entwistle et al., 2002; Gordon \& Debus, 2002; Knight, 2002; Sutherland, 2002; Tagg, 2003). The interest in teaching and learning is partly associated with attempts to enhance the effectiveness of higher education and to improve outcomes for students. It is also connected to more general questions about the role and contribution of higher education (Barnett, 2000; Martin, 1999).

The present article also focuses on teaching and learning issues, with an emphasis on quality and outcomes. It reports research that examined Zayed University students' beliefs about learning and their preferences for different types of courses and teaching. The conceptual framework for the research uses the distinction between surface and deep learning. The present analysis and data collection were prompted by assumptions that Zayed University students' prior experiences in education predispose them towards surface learning approaches. The corollary of this is that Zayed University students will hold beliefs about learning and preferences for courses and teaching that are consistent with a surface learning approach.

This corollary is examined in the present report using questionnaire responses from students as well as examples from course assessment tasks. It was expected that students would hold beliefs that emphasize the surface aspects of learning and prefer courses and teaching that are consistent with a surface approach. The research was based on a conviction that 
teaching and learning should begin with the individual students, including an understanding of their beliefs and preferences about teaching and learning. It also drew on the notion (Boyle et al., 2003) that students' understanding of the "nature of learning" is a significant influence on their approaches to learning.

In order to provide a background to the particular research questions and the methodology used, the first section of the introduction contains a brief review of research and theory about surface and deep learning approaches. Research on student essay writing as a means of assessing deep versus surface learning is then discussed. Finally, the prior educational experiences of Zayed University students is considered.

\section{Surface and deep approaches to learning}

There have been a number of attempts to provide a conceptual framework for different types or levels of learning (Biggs, 1987; Ramsden, 1992; Laurillard, 1993). A prominent example of these uses a distinction between surface and deep learning approaches. The origins of this distinction can be found in the early work of Marton and Säljö in Sweden (Marton \& Säljö, 1976; Säljö, 1979). Their research on student learning showed an emphasis on cramming and learning of facts for short-term memory. This meant a relatively superficial engagement with the material to be learned and hence more "surface" learning. They found that there was much less of an emphasis on learning for mastery and meaning, where the student attempted to gain a personal understanding of what they were learning.

The conceptual model distinguishing the surface versus deep learning approaches has been developed and clarified in recent years (Ramsden, 1992; Marton et al., 1993; Entwistle, 1997b, 1998; Biggs, 1999; McLean, 2001; Byrne et al., 2002; Gordon \& Debus, 2002; Boulton-Lewis et al., 2003; Chan, 2003; Warburton, 2003). From this literature, the following elements seem to represent a surface approach to learning:

- an intention to memorize and reproduce content according to the externally imposed requirements set by the teacher;

- accepting ideas and information passively;

- simple description;

- concentrating on the assessment requirements;

- not reflecting on the purpose of learning;

- focus on facts and procedures;

- reproducing material without analysis or integration;

- assumptions that the knowledge comes 'ready-made'.

This is reasonably consistent with what has been described as the traditional view of effective learning, namely that it involves "the passive transfer of objective knowledge from teacher to student (Biggs, 1996) with the teacher firmly in control of the students' learning and assessment testing the student's retention of knowledge" (Boyle et al., 2003, p. 268).

Features of the deep approach to learning appear to include:

- an intention to understand and extract meaning from the material;

- interacting vigorously and critically with the content;

- relating ideas to previous knowledge and experience;

- relating evidence to conclusions;

- examining the logic of arguments;

- internal motivation.

Inherent in deep learning is the notion that the understanding gained requires and arises from the development and use of a personal knowledge framework. The deep approach is based on the use of analytic skills such as cross-referencing, imaginative reconstruction and independent thinking (Warburton, 2003). This description suggests, as intimated by Boyle et al. (2003), that to achieve deep learning the student is active in the process, that the learning 
is largely self-regulated and that it is consistent with constructivist principles (Duffy \& Jonassen, 1992). Laurillard (1993) argued that in deep learning the student must master the structure of different parts to the material and the relationships among the different parts in order to gain meaning.

One reason there has been attention to the surface versus deep learning distinction is that theory and research suggests that learning outcomes for students are linked to the type of learning approach (Marton \& Säljö, 1997; Entwistle, 1998; Biggs, 1999; Prosser \& Trigwell, 1999). A deep approach to learning is assumed to be linked to higher quality learning outcomes, such as better conceptual knowledge, development of problem-solving skills, and greater mastery of content. Consistent with this claim, Zeegers (2001) showed a positive relationship between use of the deep approach and GPA in a sample of Australian science students. Other research also supports this conclusion (e.g., Sutherland, 2002).

\section{Student writing}

Student performance on essay writing has been studied as one way of assessing whether student learning has been surface or deep (Biggs, 1988; Entwistle, 1995; Biggs et al., 1999; Lavelle, Smith \& O'Ryan, 2002). This research has investigated the way in which students create meaning in their writing tasks, rather than just acquiring skills. Creating meaning is assumed to involve a deep rather than a surface approach to learning and writing. The deep approach requires active engagement with the task and the transformation of information. Further, a deep approach to writing implies analysis and synthesis of information and awareness of how writing functions, what the reader wants or expects, and how "voice" is used and expressed through writing. This means that writing with meaning requires coherent beliefs about what the reader assumes or expects when reading.

\section{Students' experience of teaching conducive to surface learning}

The prior learning experiences of students are presumed to be important factors in the beliefs and expectations they bring to the learning situation (Dunkin \& Biddle, 1974; Ramsden, 1992; Biggs, 1993; Ramsden, 1997; Entwistle et al., 2002; McLean, 2001; Zeegers, 2001). Therefore, it is important to consider the prior experiences of Zayed University students. Commentators on Arab education processes have noted that throughout the school system there is an emphasis on rote learning, memorization, and examinations that require the retention of answers to fixed questions that reward passive knowledge recipients (Rugh, 2002). This captures some of the main prior educational experience of students who attend Zayed University. These types of education processes have been identified as those most likely to contribute to surface learning approaches. (Ramsden, 1992; McLean, 2001; Zeegers, 2001; Kreber, 2003)

Another factor that is relevant to ZU students' possible orientation to surface learning is Ramsden's (1997) argument that if previous knowledge is limited, then students are more likely to adopt a surface approach. This comment could apply to ZU students because the instruction is in their second language and much of the content covers subject-matter that is new to them. Finally, if students have had previous success with a surface approach, and this appears to be the case for this group of students (because they were successful in a school system that emphasized the surface approach), they are more likely to follow it.

\section{Goals of the research}

The present research had three main goals. The first was to examine Zayed University students' beliefs about the nature of learning. The second was to examine the students' course and teaching preferences. Both of these goals were pursued using subscales from the Approaches and Study Skills Inventory for Students (ASSIST) questionnaire (Entwistle, 1997a; Tait \& Entwistle, 1996), which has now been utilized in several studies in Western countries. The subscales of the ASSIST questionnaire have separate items pertaining to a 
surface learning approach and a deep learning approach. The third goal was to determine whether examples of Zayed University student writing in a course that encouraged a deep approach contained the type of evidence suggested by Biggs (1988), Biggs et al. (1999) and Lavelle et al. (2002) as being consistent with deep learning.

\section{Method}

\section{Participants}

The participants in the research were 38 Zayed University students enrolled in a baccalaureate course on parenting in the College of Family Sciences. All students in the university are female. The language of instruction was English and for all students this was their second language, with Arabic as their mother tongue. The students were mostly aged between 21 and 23 years of age and had attended the university directly from school. Prior to taking this course on parenting the students had spent between two and four years in the university undertaking preparatory courses in English and other foundation skills for up to two years and in addition two years of general education. The students then joined their area of major study for two further years. The parenting course was part of the major in the College of Family Sciences.

\section{Preliminary work}

Two subscales from the ASSIST questionnaire were selected to examine Zayed University students' beliefs and preferences. The first subscale was Part A "What is learning?" and the second subscale was Part C "Preferences for different types of course and teaching". The items in these two subscales were discussed with several faculty with extensive experience of Zayed University students in order to assess the meaning and relevance of the items. The items were also assessed against the teaching environment at Zayed and the usual experiences of students (for example, classes are all small and there are no large lectures). Discussions were also held with a small number of students in order to assess their interpretation of the items.

As a result of this preliminary work a number of changes in wording were made in the questionnaire items. An item in Part A that read "understanding new material for yourself" was changed to "understanding new ideas and information for yourself". In Part C, the item that read "exams or tests which need only the material provided in our lecture notes" was changed to "assignments or tests which need only the material provided in our classes". The item that read "courses in which it's made very clear just which books we have to read" was changed to "courses in which it is made very clear just what we have to read". The item that read "books which give you definite facts and information which can easily be learned" was changed to "readings which give me definite facts and information which can easily be learned". The item that read "lecturers who encourage us to think for ourselves and show us how they themselves think" was changed to "teachers who encourage us to think for ourselves and show us how they think". The item that read "exams which allow me to show that l've thought about the course material for myself" was changed to "assignments or exams which allow me to show that I have thought about the course material myself". The item that read "courses where we're encouraged to read around the subject a lot for ourselves" was changed to "courses in which we are expected to find new reading and ideas for ourselves". The item that read "books which challenge you and provide explanations which go beyond the lectures" was changed to "readings which challenge me and provide explanations which go beyond the classes". 


\section{Procedure}

The two questionnaires "Beliefs about Learning" and "Course and Teaching Preferences" were placed on the course website. The two questionnaires were introduced to students in class. The purpose of the questionnaires was explained in terms of the teacher's desire to learn more about the beliefs and preferences of students as a step to understanding students and improving his teaching. No mention was made of the questionnaires covering surface or deep learning, nor that the items could be grouped in any way. It was explained that a report would be provided to the class on student responses and the teacher's interpretation of the responses. Students were informed that there were no right or wrong answers and that their responses were not part of any course assessment. They were told that while they were encouraged to complete the questionnaires, it was a voluntary activity. About $70 \%$ of the students completed the questionnaires.

The discussion introducing the questionnaires also covered an explanation of each of the items and how to use the rating scales. This included a discussion of key words, such as "assignments", "readings", and "acquired". It also meant discussion of central concepts such as what it means to understand ideas and information for yourself. Students completed the questionnaires in their own time outside of class.

A five-point scale from "very close to my beliefs" to "very different to my beliefs" was used for the questionnaire on Beliefs about Learning. For the questionnaire on Course and Teaching Preferences a four-point scale from "I definitely like" to "I definitely dislike" was used. The original also included a mid-point rating of three when the student was "unsure". In order to encourage the present students to indicate a preference, the category of unsure was not used.

\section{The questionnaires}

The "Beliefs about Learning" questionnaire contained three items consistent with a surface learning approach and three items consistent with a deep learning approach. These two sets of items are set out in Table 1. 
Table 1. Perecentage responses to each item in the Beliefs about Learning

(Students were asked to rate how close each of the items is to their beliefs)

Surface learning beliefs

Learning means

$\begin{array}{ccccc}\text { not } & \text { rather } & \text { very } & \text { different } & \text { very } \\ \text { so } & \text { close } & \text { close } & & \text { different } \\ \text { close } & & & & \end{array}$

1. making sure you remember things well

28

$53-13$

6

0

2. building up knowledge by acquiring facts and information

$\begin{array}{lllll}73 & 25 & 2 & 0 & 0\end{array}$

3. being able to use the information you have acquired

$\begin{array}{lllll}55 & 41 & 4 & 0 & 0\end{array}$

Deep learning beliefs

Learning means ...

4. developing as a person

58

$\begin{array}{llll}38 & 4 & 0 & 0\end{array}$

5. understanding new ideas and information for yourself

63

6. seeing things in a different and more meaningful way

$\begin{array}{lllll}51 & 39 & 10 & 0 & 0\end{array}$

The "Course and Teaching Preferences" questionnaire contained four items indicating a preference for courses and teaching that encourage surface learning and four items indicating a preference for courses and teaching that encourage deep learning. These two sets of four items are given in Table 2. In the actual questionnaires completed by students the items were randomly organized and no mention was made of surface or deep learning. 
Table 2 Percentage responses to each item in the Course and Teaching Preferences questionnaire Preferences questionnaire

(students were asked to rate how much they liked or disliked each type of course or teaching)

\begin{tabular}{|c|c|c|c|c|}
\hline Surface learning preferences & definitely & $\begin{array}{l}\text { like to } \\
\text { some } \\
\text { extent }\end{array}$ & $\begin{array}{l}\text { dislike } \\
\text { to } \\
\text { some } \\
\text { extent }\end{array}$ & $\begin{array}{c}\text { Definitely } \\
\text { extent } \\
\text { dislike }\end{array}$ \\
\hline 1. teachers who tell us exactly what to put down in our notes & 51 & 39 & 10 & 0 \\
\hline $\begin{array}{l}\text { 2. assignments or tests which need only the material provided in } \\
\text { our classes }\end{array}$ & 37 & 51 & 8 & 4 \\
\hline $\begin{array}{l}\text { 3. courses in which it is made very clear just } \\
\text { what we have to read }\end{array}$ & 42 & 47 & 8 & 3 \\
\hline $\begin{array}{l}\text { 4. readings which give me definite facts and information } \\
\text { which can easily be learned }\end{array}$ & 66 & 26 & 8 & 0 \\
\hline Deep learning preferences & & & & \\
\hline $\begin{array}{l}\text { 5. teachers who encourage us to think for ourselves } \\
\text { and show us how they think }\end{array}$ & 58 & 36 & 6 & 0 \\
\hline $\begin{array}{l}\text { 6. assignments or exams which allow me to show } \\
\text { that I have thought about the course material myself }\end{array}$ & 26 & 46 & 22 & 6 \\
\hline $\begin{array}{l}\text { 7. courses in which we are expected to find } \\
\text { new reading and ideas for ourselves }\end{array}$ & 55 & 40 & 3 & 2 \\
\hline $\begin{array}{l}\text { 8. readings which challenge me and provide } \\
\text { explanations which go beyond the classes }\end{array}$ & 42 & 52 & 3 & 3 \\
\hline
\end{tabular}

\section{Student essay writing}

Students completed a number of essay assignments during the course. They were encouraged and helped to construct answers showing evidence of deep learning. This is illustrated by the assessment criteria students were told would be used. These criteria included: evidence of using information from reading or from interviews they conducted to support an argument and their own point of view (not passive description from reading or from class materials), using evidence to support and explain points being made, drawing conclusions, writing paragraphs with clear themes and development of ideas, and showing that knowledge is linked and organized (not just strings of isolated pieces of information). This set of emphases is consistent with the literature on deep learning in essay writing.

\section{Results}

The results for the questionnaires are presented first and then there is an analysis of student writing from essay assignments. The questionnaire results are given in terms of the percentages of students responses to each item. The results for "Beliefs about 
Learning" are given in Table 1 and the results for "Course and Teaching Preferences" are given in Table 2. Because of the small sample size, the results are treated descriptively and are used to indicate possible trends rather than statistically significant findings. The results should be treated as initial and exploratory only.

From Table 1 it can be seen that the students generally supported each of the items as being consistent with learning. This suggests that they saw learning as comprising a number of separate elements. When focusing on the highest rating, that the item is "very close" to their beliefs, it can be seen that most support was for the item on learning being about acquiring facts and information. This is in the surface learning group. At the same time, the item that received the lowest support for being "very close" to their beliefs, "making sure you remember things well", was also in the group pertaining to surface learning. It can be seen that almost all students rated the three items about deep learning as either "very close" or "quite close" to their beliefs.

From Table 2 it can be seen that the responses suggest some variation among the items in the strength of student preferences. If the highest rating of "definitely like" is the focus, it can be seen students had a particularly strong preference for readings that provided clear facts and information that can be easily learned. They also seemed to have a strong preference for teachers who encourage them to think for themselves, as well as courses where they are expected to find new ideas and readings for themselves. These latter two items were in the group supporting deep learning while the former one (the strongest preference) was in the group supporting surface learning.

When attention is directed in Table 2 to items where there was an apparently lower rating of "definitely like", it can be seen that only $26 \%$ of students definitely like assignments or exams which allow them to show that they have thought about the course material themselves. In fact, there were $28 \%$ of the students who rated this item as being disliked to some degree. It is evident from the results that a small number of students showed a dislike for each of the other types of courses and teaching

Finally, there was no strong overall evidence that students preferred courses and teaching that encouraged surface learning more than they preferred courses and teaching that encouraged deep learning. The average percentage rating of "definitely like" for the four items in the surface learning group was 49, with the average percentage rating of "definitely like" for the four items in the deep learning category group being 45 . The fact that the highest preference was for one item in the surface category and the lowest preference was for an item in the deep category is probably important here.

This set of results suggests that a large proportion of this sample of Zayed University students held beliefs and preferences that included support for deep learning. When the results were summarized and discussed in class, there was strong acknowledgement from many students of the importance of deep learning. The questionnaire results and subsequent class discussion provided support for the teaching and assessment strategies being pursued in the course towards an outcome of deep learning. The assessment tasks, in particular were designed to enable and encourage responses showing deep learning.

\section{Student essay writing}

The following two paragraphs are taken from student reflections at the end of the course about what constitutes "good" parenting. This task asked them to integrate across many areas of the course, express a point of view, and explain and support that point of view. The examples are illustrative of a great deal of writing of the same kinds during and at the end of the course. 
First example: "I learned from the interviews that good parents often see that their children are their life and everything else comes second to them. In addition, one father said to me that he always ask his son to tell him what happened to him in the day. He is sitting down with his son and listening to him as nothing else in the world matters to him. That thing lets children feel that there is a person who cares, aware about them and they feel free to talk with their parents as friends".

In this first example, the student has clearly developed and used her own knowledge framework. She has integrated information obtained from class material and information gained from an interview with a parent. Her meaning was created in her own words as she wrote about one aspect of being a good parent. A strength of this piece as an example of deep learning is the way the student supports and explains her points. She uses the interview to support and explain her opening point. She then goes on to explain why spending time with and listening to your child can have positive benefits. This shows clear evidence of the analysis and synthesis of information that is a feature of deep learning.

Second example: In this example the student is writing about the prevention of misbehavior as one thing that good parents do. "Only good parent can think of good ways to prevent the child misbehave before it happens. One of the most important ways is to have a strong and positive relationship with your child. This means that parents should try to be good friend with their children, listen and share the child's problems. This includes love, security and emotional attachment. Also give your child a chance to say what he needs or what is his/her opinion. Don't ever control your child but have him share his thoughts with you. All of this can help to have a connection between the child and his parent. Moreover, this will destroy the distance between the child and his parent".

In this second example, the student has also developed her own knowledge framework. This is shown by how she has used components of topics we covered in class, but used them as her own by organizing them according to the theme she was developing about having a positive relationship with your child as a way of preventing misbehavior (and good parents will do this). This is clear evidence of the analysis and synthesis of information as well as creating meaning about strategies that good parents use.

\section{Discussion}

The present research was undertaken in conjunction with a course on parenting at Zayed University. The assumption was the prior experience of Zayed University students with structured examination-based education would mean that they would have preconceptions of learning that emphasized surface elements, and they would have preferences for teaching and assessment strategies that used surface learning. The pressures and difficulties of learning in a second language were also expected to be a factor orienting students mainly to a surface learning approach.

The questionnaire results for both beliefs and preferences revealed that while there was evidence of an orientation to surface learning among the students, the evidence was just as sound for an orientation to deep learning. Overall, therefore, the questionnaire results showed a complex view of learning and a set of preferences that included a strong component of deep learning for most, but not all, students. The results suggest that these students, who were towards the end of their baccalaureate program, viewed learning as containing both knowledge acquisition and meaningful change at a personal level. To draw further conclusions from the questionnaire findings, it is helpful to consider some of the results in detail. 


\section{Beliefs about learning}

The questionnaire on Beliefs about Learning showed there was reasonable support for each of the six items and therefore that students' overall beliefs about learning included both surface and deep elements. When the results were explained to the classes, suggesting that their beliefs supported both surface and deep learning, the response from most students were basically: "but of course". The strongest two beliefs were first that learning means building up knowledge by acquiring facts and information and second that learning means understanding new ideas and information for yourself. The first is consistent with surface learning and the second with deep learning.

In the case of the second belief it is difficult to interpret the way in which the students understood the key phrase "for yourself" in this item. This was explained and discussed with students before they completed the questionnaire. It is still possible that the responses were based mainly on the idea of "understanding" new ideas and information, more than understanding them "for yourself". The other two items in the deep learning group appeared to be relatively clear-cut for students to comprehend and the subsequent class discussion reinforced strong support for these two beliefs among most of the students.

There are challenges in comparing the present results on beliefs about learning with those from the international literature. This is because much of the research on student views about learning used interviews, where students had to articulate and explain their view of learning. Much of this research suggests that when interviewed, few students articulate a personal view of learning that could be described as deep. The research of Marton et al. (1993) is an example. Their research was on Open University students in Britain doing a course on Social Science Foundations, which required students to question aspects of themselves and society. This should prompt higher level conceptions of learning; nevertheless, the researchers reported that deep learning views were not typical of the students. In fact they concluded that "it is an important result to show that such a conception can actually be found" (p. 299).

The results of McLean (2001) on South African medical students also showed that deep learning views were limited. In this case they occurred mainly for students who were performing above average. Finally, Boulton-Lewis et al. (2003) used interviews to examine conceptions of learning amongst 15 Indigenous Australians over the three years of their degree course. Their results showed that all but three of the students held core conceptions of learning that were classified as surface.

The students in the present study appeared to comprehend and complete the questionnaire with little difficulty. The class discussion showed that the concepts of surface and deep learning were meaningful to the students. This supports arguments that there are common elements to conceptions of learning across cultures (Zeegers, 2001; Boulton-Lewis et al., 2003).

\section{Student use of surface and deep approaches}

Much of the research has been on student conceptions of learning (e.g., Marton et al.1993; McLean, 2001). This means asking questions such as what students understand by the terms "knowledge" and "learning" and at what point do they conclude that they have "learned" something. In contrast, there is other research on the approach that students actually use. This latter research deals with how much students engage in learning behaviors that are consistent with the surface or deep approach.

There is conflicting evidence about the use of surface and deep approaches by tertiary students. Some of this evidence suggests greater use of deep than surface approaches (e.g., Zeegers, 2001; Diseth, 2002; Gordon \& Debus, 2002; Chan, 2003). 
However, often this greater use is linked to particular conditions. For example, the students might have been exposed to constructivist kinds of teaching (Gordon \& Debus, 2002; Chan, 2003), or be students who are older and more mature (Zeegers, 2001). Science students are more likely to use a surface approach than Arts students (Biggs, 1987). Other evidence suggests that students in higher education use surface approaches more than deep approaches (Watkins \& Hattie, 1985; Ramsden, 1987; Entwistle \& Tait, 1990; Gow \& Kember, 1990; Marton \& Säljö, 1997; Zeegers, 2001; Gordon \& Debus, 2002). There are other findings suggesting that a deep approach develops over the course of the degree (Marton et al., 1993; Eklund-Myrskog, 1997), or emerges in a delayed way towards the end of the degree (Trigwell \& Prosser, 1991; Ramsden, 1992; Gordon \& Debus, 2002). Finally, we need to keep in mind evidence (e.g., Long, 2003) that many students use a combination of both surface and deep approaches.

The present research did not measure the actual approaches used by students. The results obtained here showing beliefs (and preferences) consistent with both surface and deep approaches suggest that under conducive teaching and learning conditions, Zayed University students should use some of the deep learning approaches. The results from the essay assignments are consistent with this suggestion. These comments are mainly speculative, however, and there is a need for research on just what approaches are used by Zayed University students.

\section{Student preferences}

The responses about course and teaching preferences revealed a strong preference for most of the items supporting surface learning. The students liked and preferred a good deal of structure and support in their learning. For example, they had moderately clear preferences for being told what they should note or pay attention to, and courses that make clear what has to be read. Their strongest preference was for readings that have clear facts and information that can easily be learned. This can be interpreted in the context of problems these students face with instruction being in their second language. Most of the reference materials used at Zayed University, such as books, articles, and internet websites, have been prepared with native speakers of English in mind. This means that these materials often create significant challenges for students in gaining information, mastering concepts, and achieving understanding. They would prefer material that helps them in this process.

But the responses showed strong support also for the items that pertain to deep learning, with the possible exception of item 6 . After "readings that give clear facts and information" (item 4), the next strongest preference was for teachers who encourage students to think for themselves. The participants also showed a liking for courses and teaching that required them to find new readings and ideas for themselves. The latter is connected to deep learning only when sufficient time is provided to allow students to find these additional ideas and resources. Most students also liked readings that challenged them and went beyond the classes. This is not inconsistent with the fact that the students also expressed a preference for readings that are clear in the information.

It appeared that the lowest preference was shown for "assignments or exams which allow me to show that I have thought about the course material myself". If "thought about it myself" was interpreted by the students as processing the course material into a conceptual framework that is meaningful and can be used, or as expecting them to have an opinion on the course material, or as being able to make evaluative judgments on the course material, it could be concluded that these are not things to which students are attracted. However, it is also possible that the students were expressing anxiety about going beyond what has been taught and has been learned. Examinations are a stressful experience and these students could be expressing a concern about 
facing examination questions that require interpretation and explanation that goes beyond what was covered directly in the course.

\section{Deep learning outcomes}

The analysis of the student essay responses revealed some ways in which the students displayed deep learning outcomes. This was shown especially in terms of their creation of meaning in their writing. Other research has shown how students create meaning in essays, with this taken as evidence of deep learning (Biggs,1988; Biggset al., 1999; Lavelle et al., 2002). The present essay responses also provide an illustration of students transforming information into their own cognitive frameworks and using it for their own purposes rather than passively reproducing information. A significant feature of the writing from most students in this course was that they seemed to have mastered the concept of "voice" in their writing. This means they had a sense of expressing their own viewpoint, but doing so in a way that was intended to explain this for the reader.

Whether or not students show deep learning is dependent not only on the type of assessment task, but also on the course expectations and the teaching/learning strategies used in the course (Ramsden, 1992; McKernan, 1994; Ramsden, 1997; Gordon \& Debus, 2002; Knight, 2002; Tagg, 2003; Warburton, 2003). As argued by Warburton (2003), the first step to deep learning is that students need to have a high level of engagement with the topic of learning. This implies also that the topic has a good level of relevance and generates personal interest. Many of these qualities were relatively easy to achieve in a course about parenting for this group of students. The literature outlines a large number of strategies conducive to deep learning, but full discussion of these is beyond the scope of the present article. However, a critical point is that students need sufficient time and "space" to reflect, make connections, and achieve understanding.

\section{Limitations of this study}

The present data can only be treated as tentative and exploratory. This was a small sample of students and the validity of the questionnaire has not been established for U.A.E. students. Therefore, it is difficult to have full confidence in interpretations of the student responses. Further research is needed to validate this and other instruments on student beliefs about learning and their teaching preferences, as well as their reported approaches to learning.

\section{Future directions}

The first goal of the present research was to examine student beliefs about learning. A next stage for research would be to determine the actual approach to learning that students use. This would need to acknowledge that in addition to using approaches based on surface and deep learning, Zayed University students could also employ a third approach that has been identified. This is the "strategic approach" (Byrne et al., 2002; Diseth \& Martinsen, 2003), also known as the "achieving approach" (Biggs, 1993; Gordon \& Debus, 2002). There are no particular beliefs about learning or preference for particular courses and teaching associated with the strategic or achievement approach. Rather, students use either surface or deep approach according to their needs. The over-riding feature of the strategic/achievement approach is that students' intention are to obtain the best grades by managing their time and capacities in the best way they can to meet what is necessary to obtain high grades.

The beliefs, preferences, and essay responses of the present students showed clear evidence for use of the deep approach by Zayed University students. It needs to be recognized, however, that whether students use this approach and obtain these kinds 
of outcomes is linked not only to students' preconceptions and expectations. It is also very closely linked to the teaching and learning environment provided by the course and the instructor. As noted throughout, some kinds of teaching and learning environments encourage a surface approach and other environments encourage a deep approach. The Zayed University student population appears to hold preconceptions of learning that are consistent with a deep approach. Whether students actually use this approach will depend largely on the learning and assessment context provided by the course and the instructor. A relevant factor here could be, as Biggs (1987) showed, deep learning is less evident in science courses than in arts courses. But, as revealed in the study by Zeegers (2001), among science students some may take a more surface approach while others are more oriented to deep learning. Future research at Zayed University could also focus on differences in beliefs and outcomes for students according to the type of course (e.g. social sciences versus physical sciences) and according to the learning environment associated with the particular course.

\section{References}

Barnett, R. (2000). Realizing the University in an Age of Supercomplexity. Open University Press, Buckingham, UK.

Biggs, J. B. (1987). Student approaches to learning and studying. Melbourne: ACER.

Biggs, J. B. (1988). Approaches to learning and essay writing. In R. R. Schmeck (Ed.), Learning strategies and learning styles (pp. 185-226). New York: Plenum.

Biggs, J. B. (1993). From theory to practice: A cognitive systems approach. Higher Education Research and Development, 12, 73-85.

Biggs, J. B. (1996). Enhancing teaching through constructive alignment. Higher Education, 32, 347-364.

Biggs, J. B. (1999). Teaching for quality learning at university: What the student does. Buckingham: Open University Press.

Biggs, J. B., Lai, P., Tang, C., \& Lavelle, E. (1999). The effect of a graduate workshop on graduate students writing in English as a second language. British Journal of Educational Psychology, 69, 293-306.

Boulton-Lewis, G. M., Wilss, L., \& Lewis, D. (2003). Dissonance between conceptions of learning and ways of learning for Indigenous Australian university students. Studies in Higher Education, 28, 79-89.

Boyle, E. A., Duffy, T., \& Dunleavy, K. (2003). Learning styles and academic outcomes: The validity and utility of Vermunt's inventory of learning styles in a British higher education setting. British Journal of Educational Psychology, 73, 267- 290.

Byrne, M., Flood, B., \& Willis, P. (2002). Approaches to learning of European business students. Journal of Further and Higher Education, 26, 19-28.

Chan, K-W. (2003). Hong Kong teacher education students' epistemological beliefs and approaches to learning. Research in Education, 69, 36- 50.

Diseth, A. (2002). The relationship between intelligence, approaches to learning and academic achievement. Scandinavian Journal of Educational Research, 46, 219-230.

Diseth, A., \& Martinsen, O. (2003). Approaches to learning, cognitive style, and motives as predictors of academic achievement. Educational Psychology, 23, 195- 207.

Duffy, T. M., \& Jonassen, D. H. (Eds.) (1992). Constructivism and the technology: A conversation. Hillsdale, NJ: Erlbaum. 
Dunkin, M. J., \& Biddle, B. J. (1974). The study of teaching. New York: Holt Rinehart \& Winston.

Eklund-Myrskog, G. (1997). The influence of the educational context on student nurses' conceptions of learning and approaches to learning. British Journal of Educational Psychology, 67, 371-381.

Entwistle, N. J. (1995). Frameworks for understanding as experienced in essay writing and in preparing for examinations. Educational Psychologist, 30, 47-54.

Entwistle, N. J. (1997a). The Approaches and Study Skills Inventory (ASSIST). Edinburgh: Centre for Research on Learning and Instruction, University of Edinburgh.

Entwistle, N. J. (1997b). Reconstituting approaches to learning: A response to Webb. Higher Education, 33, 213-218.

Entwistle, N. J. (1998). Approaches to learning and forms of understanding. In B. Dart \& G. Boulton-Lewis (Eds.), Teaching and learning in higher education (pp. 72-101). Camberwell, Victoria: ACER.

Entwistle, N. J., McCune, V., \& Hounsell, J. (2002). Approaches to studying and perceptions of university teaching-learning environments: Concepts, measures and preliminary findings. Occasional Report 1, September. Enhancing teaching-learning environments in undergraduate courses project. Higher and Community Education, School of Education, University of Edinburgh.

Entwistle, N. J., \& Tait, H. (1990). Approaches to learning, evaluations of teaching, and preferences for contrasting academic environments. Higher Education, 19, 169-194.

Gordon, C., \& Debus, R. (2002). Developing deep learning approaches and personal teaching efficacy within a preservice teacher education context. British Journal of Educational Psychology, 72, 483-511.

Gow, L., \& Kember, D. (1990). Does higher education promote independent learning? Higher Education, 19, 307-322.

Knight, P. T. (2002). Being a teacher in higher education. Buckingham, UK: Open University Press.

Kreber, C. (2003). The relationship between students' course perceptions and their approaches to studying in undergraduate science courses: A Canadian experience. Higher Education Research and Development, 22, 57-75.

Laurillard, D. (1993). Rethinking university teaching: A framework for the effective use of educational technology. London; Routledge.

Lavelle, E., Smith, J., \& O'Ryan, L. (2002). The writing approaches of secondary students. British Journal of Educational Psychology, 72, 399-418.

Long, W. F. (2003). Dissonance detected by cluster analysis of responses to the approaches and study skills inventory for students. Studies in Higher Education, 28, 21-35.

Martin, E. (1999) Changing Academic Work: Developing the Learning University. Open University Press, Buckingham.

Marton, F., Dall'Alba, G. \& Beaty, E. (1993). Conceptions of learning. International Journal of Educational Research, 19, 277-300.

Marton, F., \& Säljö, R. (1976). On qualitative differences in learning. II- Outcomes as a function of the learner's conception of the task. British Journal of Educational Psychology, 46, 115-127. 
Marton, F., \& Säljö, R. (1997). Approaches to learning. In F. Marton, D. Hounsell, \& N. Entwistle (Eds.), The experience of learning: Implications for teaching and studying in higher education ( $2^{\text {nd }}$ ed., pp. 39-58). Edinburgh: Scottish Academic Press.

McKernan, J. (1994). Curriculum action research. London: Kogan Page.

McLean, M. (2001). Can we relate conceptions of learning to student academic achievement? Teaching in Higher Education, 6, 399-413.

Prosser, M., \& Trigwell, K. (1999). Understanding learning and teaching: The experience in higher education. Buckingham: Open University Press.

Ramsden, P. (1987). Improving teaching and learning in higher education: The case for the relational perspective. Studies in Higher Education. 12, 275-286.

Ramsden, P. (1992). Learning to teach in higher education. London: Routledge.

Ramsden, P. (1997). The context of learning in academic departments. In F. Marton, D. Hounsell, \& N. Entwistle (Eds.), The experience of learning: Implications for teaching and studying in higher education ( $2^{\text {nd }}$ ed., pp. 198-216). Edinburgh: Scottish Academic Press.

Rugh, W. A. (2002). Arab Education: Tradition, growth and reform. The Middle East Journal, 56, 396-414.

Säljö, R. (1979). Learning in the learner's perspective. I. Some common-sense conceptions. Reports from the Department of Education, University of Goteborg, No. 76.

Sutherland, T., (2002). New conversations about learning: Insights from neuroscience and anthropology, cognitive science, and work-place studies: Part II. Accounting Education News, Winter, 7-10.

Tagg, J. (2003). The learning paradigm college. Bolton, MA: Anker Publishing Company.

Tait, H., \& Entwistle, N. J. (1996). Identifying students at risk through ineffective study strategies. Higher Education, 31, 99-118.

Trigwell, K., \& Prosser, M. (1991). Improving the quality of student learning: The influence of learning context and student approaches to learning on learning outcomes. Higher Education, 22, 251-266.

Warburton, K. (2003). Deep learning and education for sustainability. International Journal of Sustainability in Higher Education, 4, 44-56.

Watkins, D., \& Hattie, J. (1985). A longitudinal study of the approaches to learning of Australian tertiary students. Human Learning, 4, 127-141.

Zeegers, P. (2001). Approaches to learning in science: A longitudinal study. British Journal of Educational Psychology, 2, 115-132.

\section{About the Author}

Dr Alan Russell is Professor of Human Development in the College of Education, Zayed University. His primary research interest is in the transition from youth to adulthood in the U.A.E, especially the contribution of family and school-related factors. His second main research focus is teaching and learning in higher education. He has wide interests in the organization and role of higher education as well as outcomes for students. 